Original Article

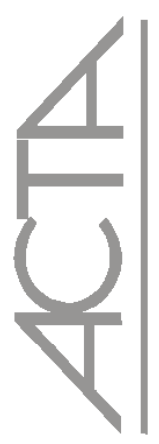

\title{
The influence of violent TV cartoons watched by school children in Turkey
}

\author{
Influência dos desenhos animados violentos assistidos na televisão por escolares da Turquia \\ Influencia de los dibujos animados violentos vistos en la televisión por escolares de Turquia
}

\author{
Sibel Ergün ${ }^{1}$
}

\begin{abstract}
Objective: This study aimed to demonstrate the gender-specific impact of violence-oriented television cartoons on children, and to identify the behaviors demonstrating this influence. Methods: The research was conducted on a total of 300 students chosen by a simple, random method applying a stratified weight in each school. A 20-question instrument was used for data collection, using face-to-face interviews with the students which occurred during visits to primary schools. Results: A significant gender difference was noted between students' favourite cartoon shows, the type of influence those shows exerted, and the ways in which students imitated the behaviors of the cartoon characters $(\mathrm{p}<0.05)$. Conclusions: It was noted that male children were influenced by violence-oriented cartoons more than female children, and that they imitated cartoon characters more.
\end{abstract}

Keywords: Cartoons; Violence; Students; Child

\section{RESUMO}

Objetivo: Demonstrar a influência da violência nos desenhos animados da TV sobre as crianças de acordo com o gênero e o tipo de comportamentos que nelas é incutido. Métodos: A investigação foi levada a cabo na Turquia ocidental, abrangendo amostra aleatória simples de 300 alunos com base no peso amostral estratificado de 18 escolas primárias. Os questionários foram aplicados por meio de entrevistas presenciais com os estudantes das escolas do $1^{\circ}$ grau visitadas, que aceitaram participar neste estudo. Resultados: O nivel de significância foi determinado segundo o gênero, com base no tipo de desenhos animados que as crianças preferiam as condições com que eram influenciadas e a capacidade de imitarem os personagens dos desenhos animados $(\mathrm{p}<0.05)$. Conclusão: As crianças do sexo masculino além de serem mais influenciadas pelo desenhos animados violentos do que as crianças do sexo feminino, também imitam mais os personagens de tais desenhos.

Descritores: Desenhos animados; Violência; Estudantes; Criança

\section{RESUMEN}

Objetivo: Demostrar la influencia de la violencia en los dibujos animados de la TV sobre los niños de acuerdo al género y al tipo de comportamientos que les es sugerido. Métodos: La investigación se llevó a cabo en Turquia occidental, que abarcó una muestra aleatoria simple de 300 alumnos con base en el peso muestral estratificado de 18 escuelas primarias. Los cuestionarios fueron aplicados por medio de entrevistas presenciales con los estudiantes de las escuelas del $1^{\circ}$ grado que fueron visitadas y que aceptaron participar en este estudio. Resultados: El nivel de significancia fue determinado según el género, con base en el tipo de dibujos animados que los niños preferían las condiciones con que eran influenciadas y la capacidad de imitar a los personajes de los dibujos animados ( $\mathrm{p}<0.05)$. Conclusión: Los niños además de ser más influenciadas por los dibujos violentos que las niñas, también imitan más a los personajes de tales dibujos.

Descriptores: Dibujos animados; Violencia; Estudiantes; Niño

\footnotetext{
* Studied carried in University, Ballkesir School of Health, Turkey.

${ }^{1}$ PhD, RN in Nursing, Assistant Professor at the Nursing Department, Ballkesir University, Balkesir School of Health, 10100 Bahkesir, Turkey.
} 


\section{INTRODUCTION}

In today's society, the prevalence of internet and television (TV) is an indisputable fact. While at the very beginning of 1980s, there were TVs only in a limited number of houses, we can now say that there are computers and internet connection available in nearly every house. As a result of these technological developments, the messages communicated from TV screens penetrate into houses and influence children, especially those in whose minds the defense mechanisms have not yet formed ${ }^{(1)}$. In their study, authors indicated that United States households with children have an average of 2.8 television sets, and $97 \%$ of these households have at least 1 VCR or DVD player. On average, children with a bedroom television set reported that they watch 12.8 hours per week compared with those without a bedroom television set, who reported 10.7 hours per week ${ }^{(2)}$.In Turkey, there are one TV in $39.8 \%$ of the childrens' houses, $2 \mathrm{TVs}$ in $43.6 \%$ of the houses, $3 \mathrm{TV}$ s in $13.6 \%$, and 4 and more TVs in $2.7 \%$ of the the chidrens' houses $^{(3)}$.In her study, Arnas indicated that there was one TV in each house of the family in Turkey, and about half of them have 2 and more $\mathrm{TVs}^{(4)}$.

Today children are exposed to the effects of TV for too long within their daily lives ${ }^{(5)}$. Children spend much more time watching TV than participating in any other activity ${ }^{(6)}$. In a study he conducted, Larson determined that young people in America, Europe and Eastern Asia watched TV an average of 1.5 to 2.5 hours daily ${ }^{(7)}$. Authors indicated that children spent their time watching TV for 3 hours and 10 minutes $^{(8)}$. Children in Turkey watch TV for 3 or 4 hours a day on average ${ }^{(9)}$. Children spent about 900 hours at school in a year. On the other hand, they watch television 1500 hours in a year ${ }^{(10)}$. The research showed that TV was on for 4 hours and 53 minutes a day, on average, in family houses ${ }^{(11)}$. In a study that explored the role of TV as a visual and auditory stimulant in the perception and acquisition of violence elements, Emanetoğlu determined that parents and children watched TV together for an average of 4 hours on weekdays and 5 hours on the weekend, between the hours of 18.00 and $22.00^{(12)}$.

The effects of TV have been much stronger on children than on adults. This is especially true because the purposes for watching TV are different among children and adults. While adults generally watch TV for fun, children watch it for purposes of learning and recognition. Additionally, more vulnerable children try to understand the TV programs they watch and they are more influenced by them ${ }^{(13)}$. The most effective influence in the lives of children, after their parents, is TV. Cartoons are the first and most common among the types of broadcasts that children watch on $\mathrm{TV}^{(1)}$. Children in elementary school watch cartoons the most with a rate of $72,1 \%{ }^{(3)}$. In his study, Eskandari demonstrated that $60 \%$ of students sometimes watched cartoons, while $40 \%$ of them always watched $\mathrm{TV}^{(14)}$. Cartoons have been presented to children on many channels, without recognition of their useful or harmful aspects ${ }^{(1)}$. In the study by Doğan at al., it was observed that watching TV took first place as part of children's free time activities, with the most popular cartoons and prime time news programs containing the most violence ${ }^{(15)}$. Children identify with cartoon characters they choose as role models for themselves, and integrate them into their relations in their social life and into their games, and they reflect the positive or negative manners they gain from them in their lives ${ }^{(3,13)}$. In her study that examined the effects of visualmedia and the culture of violence on secondary school students, One author, determined that students were influenced by the native series they watch and this situation increased the culture of violence, with students using violence in solving their problems due to seeing it as part of a normal lifestyle ${ }^{(16)}$. According to the result of the Eskandari's research, $80 \%$ of female students and $91 \%$ of male students sometimes or always chose models from cartoons for themselves ${ }^{(14)}$.

The ability of children to restrain their motives is very weak, so they can take the aggressive behaviors of cartoon characters as a model ${ }^{(3,17)}$. Since children desire and look for power, the producer sets out from this need and creates sympathetic, strong and aggressive media heroes that can overcome every difficulty through magical and infinite powers, and solve their problems by brute force. What is important is that they become strong and armed, and they solve problems by violence. When the frequency of this kind of message combines with the loveliness of characters and also their kind-heartedness is emphasized, there is no reason left for children not to imitate these characters $^{(3,17)}$.In 2001, the Surgeon General's report on youth violence concluded that "media violence increases children's physically and verbally aggressive behavior in the short term ${ }^{(18)}$. In addition, TV has affected the studying habits of children and prevented them from doing their homework ${ }^{(3)}$.

The time that children spend in watching TV gradually increases during their childhood period; it reaches its climax around the age of 10 or 12, and it starts to decrease at puberty ${ }^{(7)}$. Especially for primary school children, the content of the programs they watch and the influence the programs leave on them increases more because attention, focus and cognitive functions form in the children of this age group. This is impacted by the content of cartoons, the susceptibility of children to that content, and the significance of the reflection of this susceptibility in their lives as behaviors ${ }^{(1)}$.

The main purpose of this research, in the light of these thoughts, is to demonstrate how children are influenced by violence-oriented cartoons on $\mathrm{TV}$, according to their gender, and through what kind of behaviors these 
influences appear. In accordance with these aims, answers were sought for the following questions:

1. Is there a significant difference in the duration of watching cartoons among children, based on gender?

2. Is there a significant difference among children's favourite cartoon group ("A" or "B", as determined by the researcher)?

3. Is there a significant difference in the level of influence on children by cartoons, based on gender?

4. Is there a significant difference in the way children imitate cartoon characters, based on gender?

5. Is there a significant difference, based on gender, in terms of children's buying items associated with their favourite cartoon characters, such as journals, books, wrappers, bags and erasers?

\section{METHODS}

This research was a descriptive study, and it was conducted in 18 Primary School in Turkey between 6 December 2010 to 28 January 2011. This study was approved by Ege University Ödemiş School of Health Research Committee with number 1357. A 20-question instrument was used for data collection, using face-toface interviews with the students which occurred during visits to primary schools.

The scope of the research included the fifth grade primary school students $(\mathrm{N}=1121)$ who were studying in 18 primary schools affiliated with the district of Ödemiş, in İzmir (Turkey), in the process of formal education during the 2010-2011 school year. Related to the sampling, 300 subjects were determined to be required through a mathematical sampling formula, the scope of which is known, and the fifth grade students of 18 primary schools were classified according to their gender, with students chosen from every school according to the stratified weight by means of a simple, random method.

The questionnaire instrument was comprised of 20 questions developed by researchers, following a literature review. The first eight questions on the instrument were prepared to determine students' sociodemographic variables, while the remaining questions were prepared to determine the degree to which students were influenced by cartoon violence. The questionnaire was pilot tested on 25 students before gathering data from the research sample with final editing to the questions based on those results. The questionnaire was then implemented though the method of face-to-face interviews with the students, which lasted approximately 15 minutes.

The data gathered as a result of the study was analysed after data entry into the computer, by the application of numerical and percentile distribution and chi-square tests, using the Statistical Package for Social Sciences (SPSS 16.0).

\section{ETHICAL CONSIDERATIONS}

Before completing the survey, students were informed about the study, and received written permission. A written consent form explaining the purpose of research was then sent to parents of students. After written consent form were signed by parents, students brought the form back to the researcher. Also, necessary permission were obtained in order to conduct the research from the Board of Education. Ege University Ödemiş School of Health Research Committee approved the study with number 1357. Prior to beginning to study, participants and their guardians signed terms of Free and Informed Constent.

\section{RESULTS}

Demographic results showed that $51.3 \%$ of the students participating in the study were male, and $48.7 \%$ were female. The majority (58\%) of these students were 11 years old: $36.3 \%$ were ten years old, and $5.7 \%$ were 12 years old. Most of them (58\%) had mothers who were primary school graduates; the majority $(42.3 \%)$ had fathers who were primary school graduates. The vast majority $(87 \%)$ of the mothers were housewives and $53.7 \%$ of the fathers were working. It was determined that the success of $45.7 \%$ of the children at school was good. Most of the participants $(88.7 \%)$ had a nuclear-type family.

It was identified that $71.2 \%$ of female and $66.2 \%$ of male children watched cartoons at most for one hour in a day, when comparing the daily duration of TV viewing, according to gender. Therefore it appeared that these female children watched cartoons for longer periods than male children. In the study, no statistically significant difference was found between gender and children's daily durations of watching cartoons $(\mathrm{p}>0.05)$ (Table 1).

Table 1. Children's daily time spent watching TV, by gender: children of 18 primary schools in Turkey, data collection period December 2010-January 2011

\begin{tabular}{lccc}
\hline $\begin{array}{l}\text { Daily durations } \\
\text { of watching } \\
\text { Cartoons (hours) }\end{array}$ & Female & Male & Total* \\
\hline$<1$ & $\mathbf{n}(\%)$ & $\mathbf{n}(\%)$ & $\mathbf{n}(\%)$ \\
\hline $2-3$ & $104(50.5)$ & $102(49.5)$ & $206(68.7)$ \\
$4-6$ & $37(47.4)$ & $41(52.6)$ & $78(26.0)$ \\
$>6$ & $4(28.6)$ & $10(71.4)$ & $14(4,7)$ \\
\hline TOTAL** & $146(50.0)$ & $1(50.0)$ & $2(0.7)$ \\
\hline $\mathrm{X}^{2}=2.584 \quad \mathrm{p}>0.05$ & & $154(51.3)$ & $300(100.0)$ \\
\hline
\end{tabular}


When the favorite cartoon group (noted as group "A" or "B", by the researcher) were examined with regard to gender, $30.1 \%$ of female and $83.1 \%$ of male children liked "Group A" (cartoons containing violence and demonstrating power), while $69.9 \%$ of female and $16.9 \%$ of male children liked the "Group B" (educational, didactic and emotion-based cartoons). A statistically significant difference was identified between children's favorite cartoon types and gender $(\mathrm{p}<0.05)$ (Table 2).

Table 2. Children's favourite cartoon group, by gender: children of 18 primary schools in Turkey, data collection period December 2010-January 2011

\begin{tabular}{lccc}
\hline $\begin{array}{l}\text { Favourite Cartoon } \\
\text { Group }\end{array}$ & $\begin{array}{c}\text { Female } \\
\mathbf{n}(\%)\end{array}$ & $\begin{array}{c}\text { Male } \\
\mathbf{n}(\%)\end{array}$ & $\begin{array}{c}\text { Total* } \\
\mathbf{n}(\%)\end{array}$ \\
\hline $\begin{array}{l}\text { Group A- } \\
\text { (Violence-Oriented) }\end{array}$ & $44(30.1)$ & $128(83.1)$ & $172(57.3)$ \\
$\begin{array}{l}\text { Group B - } \\
\text { (Didactic- }\end{array}$ & $102(69.9)$ & $26(16.9)$ & $128(42.7)$ \\
Emotion-Based) & $146(48.7)$ & $154(51.3)$ & $300(100.0)$ \\
TOTAL** & & & \\
\hline $\mathrm{X}^{2}=85.996 \quad \mathrm{p}<0.05$ & & &
\end{tabular}

When the most impactful features of the cartoons children watch were compared, it was noted that $5.5 \%$ of female and $20.8 \%$ of male children were influenced by the behaviors of cartoon characters: $25.3 \%$ of female and $29.9 \%$ of male children were influenced by the extraordinary behaviors of the characters. A smaller number of female and male children (10.3\% and $9.1 \%$, respectively) were influenced by the speech of the characters. The theme of the cartoons influenced $16.4 \%$ of female and $7.8 \%$ of male children, while the music in the cartoons influenced $10.3 \%$ of female and $5.2 \%$ of male children. A statistically significant difference was found between the most impactful features of the cartoons children watch and gender $(\mathrm{p}<0.05)$ (Table 3 ).

Table 3. Most impactful feature of cartoons children watched, by gender: children of 18 primary schools in Turkey, data collection period December 2010-January 2011

\begin{tabular}{lccc}
\hline Most impactful feature & $\begin{array}{c}\text { Female } \\
\mathbf{n}(\%)\end{array}$ & $\begin{array}{c}\text { Male } \\
\mathbf{n}(\mathbf{\%})\end{array}$ & $\begin{array}{c}\text { Total* } \\
\mathbf{n}(\%)\end{array}$ \\
\hline $\begin{array}{l}\text { Characters' behaviours (Scenes } \\
\text { of Fighting) }\end{array}$ & $8(20.0)$ & $32(80.0)$ & $40(13.3)$ \\
Characters' extraordinary actions & $37(44.6)$ & $46(55.4)$ & $84(27.7)$ \\
Characters' speeches & $15(51.7)$ & $14(48,3)$ & $29(9, .7)$ \\
Topic & $24(66.7)$ & $12(33.3)$ & $36(12.0)$ \\
Music & $15(65.2)$ & $8(34.8)$ & $23(7.7)$ \\
I am not influenced & $47(52.8)$ & $42(47.2)$ & $88(29.7)$ \\
TOTAL** & $146(48.7)$ & $154(51.3)$ & $300(100.0)$ \\
\hline$X^{2}=21.624 \quad \mathrm{p}=0.001$ & & &
\end{tabular}

A statistically significant difference was found between children's degrees of imitation of the cartoon characters that they watch and gender $(p<0.05)$, with boys imitating characters more often than girls $(53.9 \%$ and $38.4 \%$, respectively). When children's degrees of imitation of the cartoon characters that they watch was compared across gender, it was observed that $53.9 \%$ of male and $38.4 \%$ of female children imitated cartoon characters, by their answers of "Yes" or "Sometimes". A statistically significant difference was found between children's degrees of imitation of the cartoon characters that they watch and gender $(\mathrm{p}<0.05)$ (Table 4).

Table 4. Children's degrees of imitation of cartoon characters watched, by gender: children of 18 primary schools in Turkey, data collection period December 2010-January 2011

\begin{tabular}{lccc}
\hline $\begin{array}{l}\text { Imitation of Cartoon } \\
\text { characters }\end{array}$ & $\begin{array}{c}\text { Female } \\
\mathbf{n}(\mathbf{\%})\end{array}$ & $\begin{array}{c}\text { Male } \\
\mathbf{n}(\%)\end{array}$ & $\begin{array}{c}\text { Total* } \\
\mathbf{n}(\%)\end{array}$ \\
\hline Yes & $13(48.1)$ & $14(51.9)$ & $27(9.0)$ \\
No & $90(55.9)$ & $71(44.1)$ & $161(53.7)$ \\
Sometimes & $43(38.4)$ & $69(61.6)$ & $112(37.3)$ \\
TOTAL** & $146(48.7)$ & $154(51.3)$ & $300(100.0)$ \\
\hline
\end{tabular}

$\mathrm{X}^{2}=8.107 \quad \mathrm{p}<0.05$

A comparison across gender was done of the buying of items associated with favourite cartoon characters, (e.g., journals, books, wrappers, bags and erasers), and it was noted that $82.5 \%$ of male and $80.8 \%$ of female children bought stationery items associated with cartoon characters (e.g., journals, books, wrappers, bags, and erasers) either "Sometimes" or "Very often". Of the children who indicated they did not buy these stationery items, $50.9 \%$ were female, while $49.1 \%$ were male. No significant difference could be found between children's purchase of stationery items associated with their favorite cartoon characters and gender $(p>0.05)$ (Table 5).

Table 5. Purchasing of items related to favorite cartoon characters (e.g., journals, books, wrappers, bags, erasers), by gender: children of 18 primary schools in Turkey, data collection period December 2010-January 2011

\begin{tabular}{|c|c|c|c|}
\hline $\begin{array}{l}\text { Purchasing of items } \\
\text { related to favorite } \\
\text { Cartoon Characters }\end{array}$ & $\begin{array}{l}\text { Female } \\
n(\%)\end{array}$ & $\begin{array}{l}\text { Male } \\
\mathrm{n}(\%)\end{array}$ & $\begin{array}{l}\text { Total* } \\
\mathrm{n}(\%)\end{array}$ \\
\hline Yes & 61(53.0) & $54(47.0)$ & $115(100.0)$ \\
\hline No & $28(50.9)$ & $27(49.1)$ & $55(100.0)$ \\
\hline Sometimes & $57(43.8)$ & $73(56.2)$ & $130(100.0)$ \\
\hline Total** & $146(48.7)$ & $154(51.3)$ & $300(100.0)$ \\
\hline
\end{tabular}




\section{DISCUSSION}

When children's daily durations of watching TV was compared by gender, it was determined that $71.2 \%$ of female children and $66.2 \%$ of male children watched cartoons at most for one hour in a day. The reason why female children watch cartoons longer than male children may be that the cartoon sector knows how to attract the attention of children very well, and they accordingly make efforts for change and development. Therefore, in all cartoons presented and intended for girls, the characters who are the focus of attention are very beautiful, slim, well-dressed, equipped with super powers, struggling with evils, and are very popular among friends. This situation draws the attention of the girls who are about to step through puberty; it has been shown that girls enter puberty, especially biologically, earlier than boys and watching these kind of cartoons satisfies their desires for being loved and admired ${ }^{(1)}$. Therefore it is thought that female children watch cartoon for longer than male children.

In the study, no statistically significant difference was found between gender and children's daily durations of watching cartoons $(p>0.05)$ (Table 1). This result is thought to stem from the fact that the durations for male and female children watching cartoons in the research sample were nearly identical.

A statistically significant difference was found between children's favourite cartoon groups and gender $(p<0.05)$, (Table 2). It is possible that because the education levels of the parents of the children within the scope of our study were very low, they did not restrict their children, and therefore male children watched violence-oriented cartoons much more.

According to the findings of the study, while male children were more influenced by the behaviours and extraordinary actions of cartoon characters, female children were much more influenced by the characters' speeches, the topic of and the music in the cartoons. Either because of the chemical effect of hormones or the emotional effect the social environment causes, children at the primary school age become more aware of sexual discrimination and thereby concentration between genders starts. It is also thought that the message given by the toy baby that is bought for female children since their infancy, and by the toy car and weapon bought for male children, reflects on their choice of cartoons when they are growing up.

Imitation is a process which plays an important role in shaping the behaviours of a child. The tendency for imitating others is very strong in humans, and especially in children. Imitation contains every kind of behaviour; especially dynamic scenes and extraordinary powers attract the attention of children more. One child observes other people while they are demonstrating acts of violence or controlling their aggression, and he imitates them. He learns to shout at people, to criticize them, throw stones at them and to show violence. For them, the tendency for imitating important, strong, successful and favourite characters is so strong that this tendency for imitation is more important than the situation in which these characters find themselves fighting wars or killing enemies ${ }^{(13)}$. Hence, our male sample group that watches more action-oriented and violence-oriented cartoons, imitates the characters of action and violence-oriented cartoons more. The findings of the study show a parallel with literature.

No significant difference could be found between children's purchase of stationery items associated with their favorite cartoon characters and gender $(p>0.05)$ (Table 5).

Today it is a known fact that competition is very great, both in the toy sector and stationery products, and that there have been rapid changes. Male and female children can easily obtain every kind of item associated with their favourite cartoon characters. Thus, it is considered that children's buying habits regarding the stationery items related to their favourite cartoon characters does not depend on gender.

Finally, it was determined in the study that male and female children's durations of watching cartoons are almost identical to each other. Therefore a significant difference was not found between the durations of watching cartoons based on gender. In the study a significant difference was determined among children's favourite cartoon groups: male children liked more violence-oriented cartoons in which power was exhibited, while female children liked educational, emotional and didactic cartoons much more. According to the findings of the study a significant difference was observed in terms of the amount of influenced perceived from the cartoons, based on gender: male children were influenced by the behaviours and extraordinary actions of cartoon characters, whereas female children were influenced by the speeches of characters, and the topic of and music in the cartoons. A significant difference was determined in respect to children's conditions of imitating the actions of cartoon characters according to gender, and it was discovered that male children imitated the actions of cartoon characters much more. In the study no statistically significant difference was found in children's buying of the stationery items associated with their favourite cartoon characters and gender. According to these results, children should watch violence-oriented cartoons under the control of teachers or families. Cartoons should be analysed and the disadvantages and harmful effects of violence-oriented behaviours in them should be emphasized.

\section{Implications for nursing practice}

Nursing is a profession which consists of science and art. Although art and science generally are considered as opposed to each other, they combined the most creative way in terms of nursing. As a science, nursing requires theoretical knowledge and skills related to all aspects of child health. 
The aim of child health nursing is to ensure children's and adolecscents' physical, intellectual, emotional and social development withing the familiy and society. Today, developing and maintaining the highest level of child and family health as well as giving education, providing guidance, suppoting and defending rigts have become common in the most important objectives of the nursing ${ }^{(19-20)}$.

That nurses interacting with many parents in different roles and environments, know the effects of cartoons on child development, and provide training and consultancy services to families will be able to reduce the negative affects of cartoons on children. The fact that nurses know the effects of watching cartoons on children is very important in terms of giving guidance and education to parents.

\section{CONCLUSION}

It was determined in the study that male and female children's durations of watching cartoons are almost identical to each other. Therefore a significant difference was not found between the durations of watching cartoons based on gender. In the study a significant difference was

\section{REFERENCES}

1. Köşker N. Examination of effects of cartoons on (animation) TV for education of Primary School Students (unpublished graduate thesis) (Televizyondaki çizgi filmlerin (animasyon), ilköğretim çağ1 çocuklarının eğitimi üzerine etkilerinin incelenmesi), Gazi Üniversitesi Eğitim Bilimleri Enstitüsü, Ankara (Yayınlanmamış Yüksek Lisans Tezi). 2005. p. 42-46.

2. Borzekowski DL, Robinson TN. The remote, the mouse, and the no. 2 pencil:the household media environment and academic achievement among third grade students. Arch Pediatr Adolesc Med. 2005;159(7):607-13.

3. İrkin AÇ. Growing process of children and effects on television (Çocuklarin gelişim süreci ve televizyonun etkileri). T.C. Radyo ve Televizyon Üst Kurulu Yayınlanmamış Uzmanllk Tezi. Ankara. 2012; 38-64.

4. Arnas YA. 3-18 yaş grubu çocuk ve gençlerin interaktif iletişim araçlarını kullanma alışkanlıklarının değerlendirilmesi. Turkish Online J Educ Technol. 2005:4(4): 59-66.

5. Bağl1 MT. Evaluation of tv and radio broadcasts on the ratings and complaints (radyo ve televizyon yayınlarına ilişkin beğeni ve şikâyetlerin değerlendirmesi), rtük; 2002.

6. Aral N, Ceylan R, Bıçakçı MY. [Study of television viewing habits of children by age and gender].Kastamonu Eğitim Dergisi. 2011; 19(2): 489-98.

7. Larson RW. How U.S children and adolescents spend time: what it does (and doesn't) tell us about their development. Curr Dir Psychol Sci. 2001; 10(5):160-4

8. Gunter B, Charlton T, Coles D, Panting C. The impact of television on children's antisocial behavior in a novise television community. Child Study J. 2000; 30 (2): 65-90.

9. Sayil M.Televizyonun çocuk ve gençler üzerindeki etkileri [Internet] [cited 2012 Jul22]. Available from:http:// www.devpsy.hacettepe.edu.tr/dosyalar/annebaba/ televizyonuncocuklaruzerindekietkileri.pdf.

10. Devrimci EY. Çocuk ve televizyon: içerik ve Ötesi [Internet] [cited 2012 Jul 22]. Available from: http://panel.unicef.org.tr/vera/app/ var/files/c/o/cocuk-ve-televizyon-icerik-ve-otesi.pdf).

11. Ertürk Y, Akkor D, Gül A. Do not hand over your child to determined among children's favourite cartoon groups: male children liked more violence-oriented cartoons in which power was exhibited, while female children liked educational, emotional and didactic cartoons much more. According to the findings of the study a significant difference was observed in terms of the amount of influenced perceived from the cartoons, based on gender: male children were influenced by the behaviours and extraordinary actions of cartoon characters, whereas female children were influenced by the speeches of characters, and the topic of and music in the cartoons. A significant difference was determined in respect to children's conditions of imitating the actions of cartoon characters according to gender, and it was discovered that male children imitated the actions of cartoon characters much more. In the study no statistically significant difference was found in children's buying of the stationery items associated with their favourite cartoon characters and gender. According to these results, children should watch violence-oriented cartoons under the control of teachers or families. Cartoons should be analysed and the disadvantages and harmful effects of violence-oriented behaviours in them should be emphasized.

Televeision. Make media literacy. (Çocuğunuzu Televizyona Teslim Etmeyin. Medya okuryazarı olun). Ankara: Nobel Yayın Dağıtım; 2006. p. 35-51.

12. Emanetoğlu KH. Television Role as Auditory and Visual Stimuli for Perception and Learning of Violence Component (Şiddet Öğelerinin Alg1lanması ve Ögrenilmesinde İsitsel Ve Görsel Uyaran Olarak Televizyonun Rolü), İstanbul Üniversitesi Adli Tip Enstitüsü, Yüksek Lisans Tezi, İstanbul. 2006. p. 75-80.

13. Yavuzer H. Child and Crime (Cocuk ve Suç). İstanbul: Remzi Kitapevi 14. Basım; 2011. p. 42-60.

14. Eskandari M. Effects of Cartoons on TV in Iran on education of Primary School Students (İran'da TV'de Yayınlanan Cizgi filmlerin İlkokul Öğrencilerinin Eğitimine Etkisi), Gazi Üniversitesi Eğitim Bilimleri Fakültesi, Yüksek Lisans Tezi, Ankara. 2007. p. 1-162.

15. Doğan G, Subaşı N, Çakır B. Öztürk P, Yılmaz B, Hacıŏglu E, Özşahin M, Yeğnidemir N. Bir ilköğretim okulu 5,6,7 ve 8. sınıf ögrrencilerinin en çok izledikleri televizyon programları ve bu programların şiddet içeriği yönünden değerlendirilmesi. Çocuk Gelişimi ve Eğitimi Dergisi. 2004; 1 (10-11): 64-70.

16. Doğan G, Subaşı N, Çakır B. Öztürk P, Yılmaz B, Hacıoğlu E, Özşahin M, Yeğnidemir N. Evaluation primary school students studying at a 5., 6., 7., and 8. Classes in terms of mostly watced TV Programmes and its violence contents (Bir ilköğretim okulu 5.,6.,7. ve 8. sınıf öğrencilerinin en çok izledikleri televizyon programlan ve bu programların şiddet içeriği yönünden değerlendirilmesi). Çocuk Gelişimi ve Eğitimi Dergisi. 2004; 1 (10-11): 64-70.

17. Türk M, Bıyık A. Ekrandan Yansıyan Șiddet ve Televizyon Yayınlarının Çocuklara Etkileri. Türkiye Sosyal Araştırmalar Dergisi TSA. 2004; 8(1):178-202.

18. United States. Public Health Service. Youth violence: areport of the surgeon general. Risk. Rockville (MD): Office of the Surgeon General; 2001 [Internet]. Chapter 4,Risk factors for youth violence. Available from:http://www.ncbi.nlm.nih.gov/books/NBK44293/

19. Çavuşoğlu H. (2011). Child Health Nursing (Çocuk Sağlı̆̆1 Hemşireliği). Cilt I, Sistem Ofset, Ankara, s:19.

20. Öztürk C, Karayağız G. Çocuk ve televizyon. Atatürk Üniversitesi Hemşirelik Yüksekokulu Dergisi. 2007;10(2): 81-5. 